\title{
Habitat use by Astyanax taeniatus (Jenyns, 1842) (Characiformes: Characidae) in a coastal stream from Southeast Brazil
}

\author{
Luisa Resende Manna ${ }^{1,2}$, Carla Ferreira Rezende ${ }^{3}$ and Rosana Mazzoni ${ }^{1}$
}

The habitat use of a stream-dwelling Astyanax taeniatus from the State of Rio de Janeiro was investigated. We performed $12 \mathrm{~h}$ of underwater observation in a $200 \mathrm{~m}$ long stretch in the upper Roncador stream and quantified the following microhabitat descriptors: (i) water velocity, (ii) distance from the stream bank, (iii) substratum, and (iv) water column depth. Microhabitat selectivity was analyzed by comparing the microhabitat used by fish and the microhabitat available in the study site as well as by applying the Ivlev Electivity Index to the microhabitat use data. Differences in the use and availability of the various microhabitats revealed non-stochastic patterns of spatial occupation by A. taeniatus, which was selective for two of the four analyzed microhabitats. Our findings indicated that A. taeniatus is associated with habitats that have higher depths, low water velocity, and sand and bedrock substratum.

O uso do micro-habitat por Astyanax taeniatus de riacho do estado do Rio de Janeiro foi investigado. Realizamos $12 \mathrm{~h}$ de observações subaquáticas em um trecho de $200 \mathrm{~m}$ do alto rio Roncador e quantificamos os seguintes descritores do microhabitat: (i) velocidade da água, (ii) distância da margem, (iii) substrato, e (iv) profundidade da coluna d’água. A seletividade do micro-habitat foi analisada pela comparação do micro-habitat usado pelos peixes e o micro-habitat disponível na área de estudo, bem como pelo Índice de Eletividade de Ivlev aplicado aos dados de uso do micro-habitat. As diferenças no uso e disponibilidade dos diferentes descritores do micro-habitat revelaram um padrão não aleatório para a ocupação especial por $A$. taeniatus que foi seletivo para dois dentre quatro descritores analisados. Nossos registros indicaram que A. taeniatus está associado à habitats com maior profundidade, baixa velocidade da água e substrato de areia e rocha.

Key words: Snorkeling, Micro-habitat, Rain Forest, Non-stochastic use, Environmental resources.

\section{Introduction}

The spatial segregation of individuals due to differences in resource use is an important aspect of population and community structure (Ross, 1986; Arlettaz, 1999). Fish species have specific patterns of habitat use and feeding and reproductive strategies that allow only a few species to occupy the same space (Weatherley, 1963), and therefore, these species segregate in the available space (Roff, 1992).

The different habitats used by stream-dwelling fish can be defined at different scales. The mesohabitat represents large-scale physical units determined by the presence of riffles, runs, and pools (Angermeier \& Schlosser, 1989), and the most important differences between these units are related to water velocity and substratum. On a minor scale, the microhabitat represents specific subunits of the mesohabitats with specific physical structural components (Sedell et al., 1990). Microhabitats can be recognized in relation to the focal position of the fish (e.g., water velocity, depth) (Inoue \& Nunokawa, 2002). Heterogeneous environments provide a greater variety of microhabitats with protected places where fish can shelter themselves from predators and where they can find a wide range of food resources and sites for reproduction (Wootton, 1998).

Studies concerning the use of microhabitats are normally focused on the description of local areas used by fish (Rincón, 1999). The physical habitats and the specific microhabitat used by different species have been studied due to their influence

\footnotetext{
${ }^{1}$ Universidade do Estado do Rio de Janeiro, IBRAG, Departamento de Ecologia, Laboratório de Ecologia de Peixes. Av. São Francisco Xavier, 524, Maracanã, 20550-013 Rio de Janeiro, RJ, Brazil. mazzoni@uerj.br

${ }^{2}$ Programa de Pós-Graduação em Ecologia e Evolução, UERJ / IBRAG, PHLC, 2o andar sala 224. luisamanna@gmail.com

${ }^{3}$ Universidade Federal do Ceará, Departamento de Biologia, Laboratório de Ecologia de Rios do Semiárido. Centro de Ciências, Bloco 909, Câmpus do Pici, 60020-181 Fortaleza, CE, Brazil. carlarezende.ufc@gmail.com
} 
on the structure of stream-dwelling fish communities (Rincón \& Lobón-Cerviá, 1993; Suen \& Su, 2010; Lee \& Suen, 2012). Nonetheless, the habitats used by fish are also strongly influenced by the availability of food and resource partitioning (Gray \& Stauffer-Jr., 1999; Yamasaki et al., 2006) and the predominance of different environmental characteristics, such as water depth, flow velocity and type of substrate (Wootton, 1998; Mazzoni et al., 2011). Fish behavior and swimming performance can also cause a different spatial distribution among the species in a community (Uieda, 1984; Sabino, 1999).

Characiformes are very active fish and have very pronounced spatial exploratory behavior (Sazima, 1980). Astyanax species are prone to using different microhabitat resources (Uieda, 1984; Aranha et al., 1998; Mazzoni et al., 2004; Barreto \& Aranha, 2005), but they are more frequently found inhabiting pools and runs with moderate currents and sand and gravel substrata (Fogaça et al., 2003; Rezende et al., 2010). In the present study, we aimed to quantify the used and available resources to address whether Astyanax taeniatus (Jenyns, 1842) has a stochastic or selective use of the microhabitats in a rain forest stream in the Mata Atlântica. This species was chosen because it was the most abundant Characiform species in the studied stream and is an excellent model to address issues related to the use of environmental resources (Aranha et al., 1998; Mazzoni et al., 2004).

\section{Material and Methods}

\section{Study Area}

Fieldwork was conducted at Roncador stream, which is part of the Mato Grosso fluvial system in the Northeast of Rio de Janeiro State (22 $53^{\prime}$ 'S 42 $39^{\prime} \mathrm{W}$ ). Roncador is a secondorder stream and flows for approximately $12 \mathrm{~km}$. Its headwaters are located at $500 \mathrm{~m}$ in Serra do Mato Grosso, and it discharges into the Saquarema Lagoon. The study site was chosen because the fish density was sufficiently high to obtain numerous observations of Astyanax taeniatus and to minimize the probability of making more than one observation of the same individual. Roncador stream presents heterogeneous physical properties and a wide range of available microhabitats with different characteristics, allowing for the differentiation between stochastic and selective use of the microhabitats.

\section{Data collection and analysis}

Data records were obtained for individuals of Astyanax taeniatus in a $200 \mathrm{~m}$ long stretch of the Mato Grosso stream. Microhabitat surveys were conducted through underwater observation (snorkeling) in two sampling sessions, during the wet and the dry seasons of 2010. Each sampling session lasted for $6 \mathrm{~h}$ with sessions of $30 \mathrm{~min}$, totaling $12 \mathrm{~h}$ of underwater observation during the entire study.

The surveys were conducted in two stages: (i) quantification of microhabitat resources used by individual fish and (ii) quantification of microhabitat resources available along the study area. Microhabitat use was quantified according to a focal individual approach (sensu Altmann, 1974). At the beginning of each diving session, the diver laid calm for 10 min downstream of the site to allow the fish become accustomed to the observer, and then the diver moved from the lower to the upper section of the study site. For each observed fish, resource descriptors (Table 1) and fish size (standard length) were recorded.

Microhabitat availability was quantified along the study site. Fifty transects perpendicular to the water flow were established $5 \mathrm{~m}$ apart from each other along $245 \mathrm{~m}$ of the study site. At each transect, five microhabitat parameters (Table 1 ) were recorded in $0.4 \times 0.4 \mathrm{~m}\left(0.16 \mathrm{~m}^{2}\right)$ quadrats. The

Table 1. Microhabitat descriptors and their respective measurements for fish use and environmental availability measurements applied for the microhabitat study of Astyanax taeniatus from Roncador stream.

\begin{tabular}{|c|c|c|c|}
\hline $\begin{array}{l}\text { Environmental } \\
\text { Descriptors }\end{array}$ & Description & Use Measurement & Availability Measurement \\
\hline $\begin{array}{l}\text { Distance from the } \\
\text { nearest bank }(\mathrm{cm})\end{array}$ & $\begin{array}{l}\text { Distance from the stream bank to a given point in the stream } \\
\text { channel Measured with a measuring tape }\end{array}$ & $\begin{array}{l}\text { Distance from the stream } \\
\text { bank to the fish focal } \\
\text { position }\end{array}$ & $\begin{array}{l}\text { Distance from the stream } \\
\text { bank to a place where the } \\
\text { quadrats were placed }\end{array}$ \\
\hline $\begin{array}{l}\text { Water Velocity } \\
(\mathrm{m} / \mathrm{sec})\end{array}$ & Water velocity measured through a fluxometer probe & $\begin{array}{l}\text { Water velocity measured at } \\
\text { the fish focal position }\end{array}$ & $\begin{array}{l}\text { Water velocity measured } \\
\text { where the quadrats were } \\
\text { placed }\end{array}$ \\
\hline Stream Width (m) & $\begin{array}{l}\text { Distance from one to another stream bank. Measured through a } \\
\text { measuring tape }\end{array}$ & $\begin{array}{l}\text { Distance from one to } \\
\text { another stream bank in the } \\
\text { fish focal position }\end{array}$ & $\begin{array}{l}\text { Distance from one to } \\
\text { another stream bank where } \\
\text { the quadrats were placed }\end{array}$ \\
\hline Substratum & $\begin{array}{l}\text { Substratum types occurring in the study site: (i) mud - particles < } \\
0.2 \mathrm{~cm} \text { and subject to suspension; (ii) sand - particles } 0.2 \mathrm{~cm} \geq \\
2.5 \mathrm{~cm} \text {; (iii) gravel - particles } 2.5 \mathrm{~cm}>5.0 \mathrm{~cm} \text {; (iv) boulder - } \\
\text { particles } 5.0 \mathrm{~cm}>30 \mathrm{~cm} \text {; and (v) bedrock - particles }>30 \mathrm{~cm}\end{array}$ & $\begin{array}{l}\text { Percentage of each } \\
\text { substratum type measured } \\
\text { just below the fish focal } \\
\text { position }\end{array}$ & $\begin{array}{l}\text { Percentage of each } \\
\text { substratum type measured } \\
\text { just below the quadrats }\end{array}$ \\
\hline $\begin{array}{l}\text { Water Column } \\
\text { Depth }(\mathrm{cm})\end{array}$ & Distance from the water surface to the stream bottom & $\begin{array}{l}\text { Distance from the water } \\
\text { surface to the fish focal } \\
\text { position }\end{array}$ & $\begin{array}{l}\text { Distance from the water } \\
\text { surface to a place where } \\
\text { the quadrats were placed }\end{array}$ \\
\hline
\end{tabular}


position of each quadrat was selected among four points along the transect: (1) position on the right shore $(10 \mathrm{~cm}$ from the bank), (2) position in the first third of the channel, (3) position in the second third of the channel and (4) position on the left shore ( $10 \mathrm{~cm}$ from the bank). The sampled quadrats represented $4 \%$ of the total area of the studied stream stretch.

The substrate was classified into five categories according to particle size: mud (particles $<0.2 \mathrm{~cm}$ and subject to suspension); sand (particles $0.2 \mathrm{~cm}>2.5 \mathrm{~cm}$ ); gravel (particles $2.5 \mathrm{~cm}>5.0 \mathrm{~cm}$ ); boulder (particles $5.0 \mathrm{~cm}>30 \mathrm{~cm}$ ); and bedrock (particles $>30 \mathrm{~cm}$ ). Water velocity was classified into five categories based on Gorman (1988): very slow $(<0.10 \mathrm{~m} / \mathrm{sec})$; slow $(0.10-0.25 \mathrm{~m} / \mathrm{sec})$; moderate $(0.25-0.75 \mathrm{~m} / \mathrm{sec})$; fast $(0.75-$ $1.25 \mathrm{~m} / \mathrm{sec})$; and torrential (>1.25 m/sec). The existence of correlations among the predictor variables was tested by performing Pearson correlations between all pairs of variables.

Differences in the frequency of each category within each variable between used and available resources were evaluated using Chi-square tests with the Yates correction when necessary, using a significance value of $\mathrm{p}<0.05$ (Zar, 1999). The Electivity Index (Ei) (Krebs, 1989): Ei = (Ui - Ai)/(Ui+Ai), where $\mathrm{Ui}=$ fish proportion using resource $\mathrm{i}$ and $\mathrm{Ai}=$ available proportion of resource $i$, was applied to test the preference/ avoidance of each microhabitat resource. Ei ranges from -1 to +1 , where positive values indicate preference and negative values indicate avoidance of a given resource. Voucher specimens of $A$. taeniatus were placed at the Ichthyological Collection of Museu Nacional, Rio de Janeiro (MNRJ 29949 and MNRJ 29950).

\section{Results}

Resources available in the study site were quantified in 200 quadrats, totaling $32 \mathrm{~m}^{2}$, established within the total sampling area of $400 \mathrm{~m}^{2}$. The analysis of microhabitat availability revealed that the studied site was quite heterogeneously represented by (i) areas of pools (deep areas with low water velocity, sand, and mud substrata); (ii) areas of runs (moderate water velocity areas without visually apparent surface turbulence, with gravel and bedrock substrata); and (iii) areas of riffles (shallow and high water velocity with high, visually apparent surface turbulence and with boulder and gravel substrata) (Table 2). We observed 50 adult individuals with lengths varying from $3.9 \mathrm{~cm}$ to $6.3 \mathrm{~cm}$ (average of $5.3 \mathrm{~cm}$ ). Astyanax taeniatus was observed inhabiting the water column, organized in shoals (80\% of the observations) and, on average, $9 \mathrm{~cm}$ from the riverbank. The individuals were frequently in groups of up to 30 individuals swimming in the water column and spending much of the time foraging in environments with moderate currents. Only adult individuals (>3.8) were observed in the study site.

Correlation analysis among the predictor variables revealed two cases of significant positive correlations: distance from the nearest stream bank and stream width $\left(\mathrm{R}^{2}=0.185\right.$; $\mathrm{p}<$ $0.005)$ and water velocity and sand substrate $\left(R^{2}=0.191 ; \mathrm{p}<\right.$ $0.005)$. We eliminated stream width from further analysis but
Table 2. Environmental characterization of the study site at Roncador stream, including maximum, minimum and mean of depth; water velocity and stream width; and percentage values of substratum type: bedrock, boulder (diameter between 5.0 and $30.0 \mathrm{~cm}$ ), gravel (diameter between 2.5 and $5.0 \mathrm{~cm}$ ), sand, and mud.

\begin{tabular}{lrrr}
\hline Variable & Mean & Minimum & Maximum \\
\hline Water column depth (cm) & 23.3 & 2.00 & 75.00 \\
Water velocity (m/sec) & 0.6 & 0.00 & 4.25 \\
Channel width (m) & 3.3 & 1.05 & 6.25 \\
\hline Substratum Type & \multicolumn{3}{c}{} \\
\hline Bedrock & \multicolumn{3}{c}{} \\
Boulder & 15 & \\
Gravel & 18 \\
Sand & 15 & \\
Mud & 24 \\
\end{tabular}

retained water velocity and sand substrate due to their importance for many aspects of fish life history and microhabitat use.

Differences in the use and availability of the microhabitat descriptors revealed non-stochastic patterns of microhabitat use by A. taeniatus. The water column depth varied from 2 to $75 \mathrm{~cm}$ along the study site, but individuals of $A$. taeniatus showed significant differences $\left(\chi^{2}=24.6\right.$; $\left.\mathrm{df}=4 ; \mathrm{p}<0.001\right)$ in the use of this microhabitat. According to the Ivlev index, individuals showed a preference for depths between 30 and $75 \mathrm{~cm}$ and avoidance of depths below $30 \mathrm{~cm}$ (Fig. 1a). The water velocity varied from $0 \mathrm{~m} / \mathrm{sec}$ to $4.0 \mathrm{~m} / \mathrm{sec}$, but those between $0.25 \mathrm{~m} / \mathrm{sec}$ and $0.75 \mathrm{~m} / \mathrm{sec}$ were the most frequently used without significant differences $\left(\chi^{2}=2.8 ; \mathrm{df}=4 ; \mathrm{p}>0.25\right.$ Fig. 1b). Positive values of Ivlev index were expressed only for slow and moderate water velocities. All types of substrata occurred in similar proportions along the study site, but bedrock and sand were significantly the most used $\left(\chi^{2}=30.6\right.$; $\mathrm{df}=4 ; \mathrm{p}<0.001$ ) as shown by the Ivlev index (Fig. $1 \mathrm{c}$ ). The distance from the stream bank (lateral position) varied from 0 to $200 \mathrm{~cm}$ and presented the same incidence along the study site. The use of this variable did not show a significant difference $\left(\chi^{2}=6.8 ; \mathrm{df}=4 ; \mathrm{p}>0.25\right)$, as indicated by a close to zero Ivlev index in all positions (Fig. 1d).

\section{Discussion}

The use of habitats by fish can be related to many lifehistory features, including morphology (Wootton, 1998), reproductive requirements (Munro, 1990) and body size (Davey et al., 2005; Beyer et al., 2007). For the studied species, we recorded a clear case of size selective segregation, as only adult individuals were observed in the upstream area during the study. Following this same pattern, A. janeiroensis segregated along a coastal stream in response to reproductive requirements, and only adult (i.e., larger) individuals were found in the upstream stretches of the studied area (Mazzoni et al., 2004). This pattern of distribution explains why we limited our analysis to only adult individuals of $A$. taeniatus, and it assured that our analyses were not biased by the 
(A)

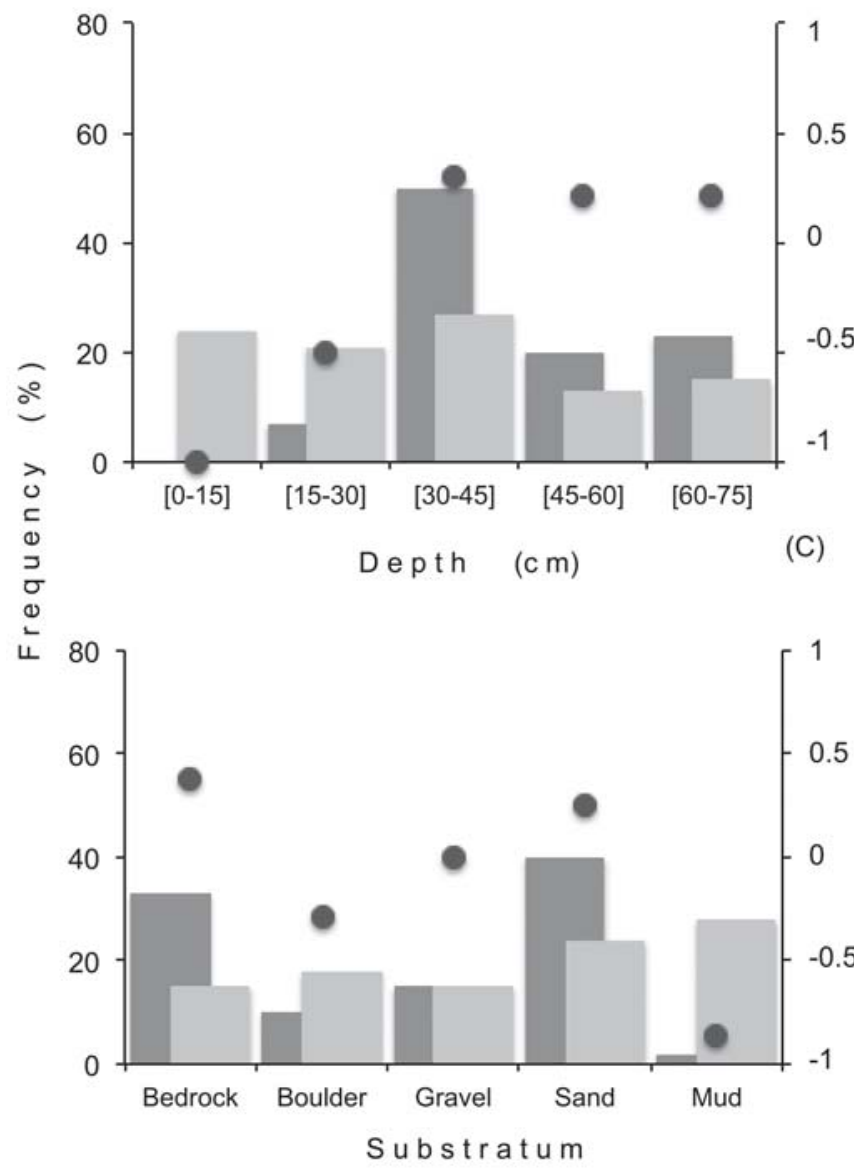

(B)
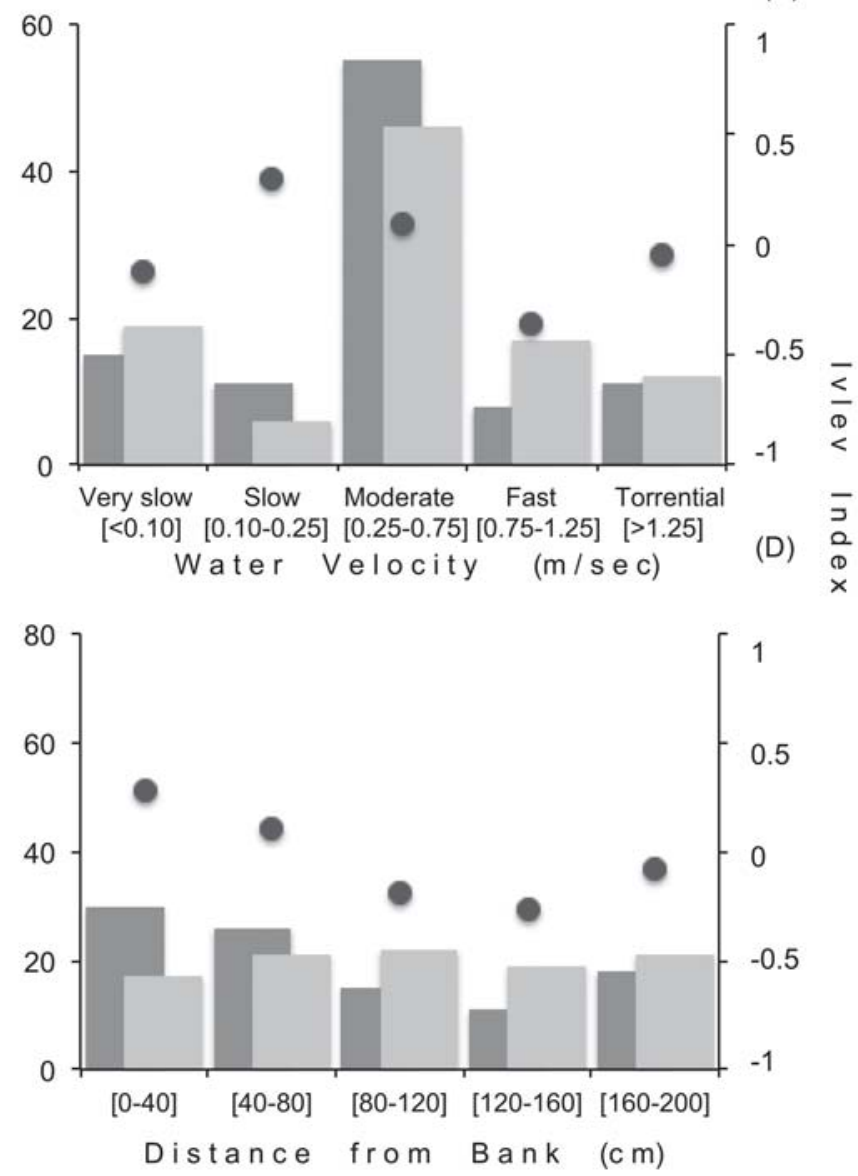

Fig. 1. Availability (light grey bars), use (dark grey bars), and Ivlev Index (black circles) for the four studied microhabitat parameters affecting Astyanax taeniatus from Roncador stream: (A) total depth; (B) focal water velocity; (C) substratum; (D) distance from the nearest bank.

specific behaviors of fish of different ages. Nonetheless, the study site contained all the mesohabitats frequently found in many rain forest streams from the Mata Atlântica (Mazzoni et al., 2011), including a combination of depths, water velocities and substrata, which represented pools, runs, and riffles, creating conditions suitable for high species diversity (Angermeier \& Schlosser, 1989; Ceneviva-Bastos et al., 2010).

Depths below $30 \mathrm{~cm}$ were avoided by the studied species; this is a typical behavior of mid-water pelagic fish (Costa, 1987; Casatti, 2002; Fogaça et al., 2003; Abilhoa et al., 2008). Concerning this position in the water column, body shape and fin morphology can influence ecological performance characteristics, such as hydrodynamics, swimming speed, maneuverability and habitat use (Motta, 1988; Gibran, 2007). Astyanax taeniatus, as well as many other Astyanax species (Uieda, 1984; Abilhoa et al., 2008), also selected slow to moderate water velocities with bedrock and sandy bottoms. Ceneviva-Bastos et al. (2010) observed two Astyanax species associated with sandy bottoms. These patterns of habitat use could be reflecting the feeding tactics frequently described for Astyanax species that forage in the water column, feeding on drift items available throughout the year in these coastal streams (Motta, 1988; Motta et al., 1995; Casatti \& Castro, 2006; Gibran, 2007). Astyanax species are highly active with a marked exploratory behavior (Fogaça et al., 2003), and this behavior was in agreement with that observed for A. taeniatus in the present study, as well as elsewhere (Manna et al., 2012). The fish collected drifting food items, mostly terrestrial plant and debris, and are therefore characterized as "drift feeders" (sensu Sazima, 1986), corroborating other studies based on Astyanax species (Costa, 1987; Casatti, 2002; Abilhoa et al., 2008).

Predation, intraspecific competition, and foraging efficiency can influence the selection for deep areas of the water column (Punchard et al., 2000), apart from the observation that shoaling behavior appears to be an important foraging strategy (Medeiros et al., 2010). This strategy could be an important factor leading to a non-stochastic spatial distribution by A. taeniatus in Roncador stream. In addition to this feature, habitat selection was recognized as a hierarchical process in which macro- and microhabitats are selected following decisions related to the reduction of 
predation risk (Kramer et al., 1997). Avoiding shallow waters has been reported as a strategy related to reduce predation risk and to avoid refuge-poor areas (Liefferinge et al., 2005). In fact, the shallow areas of these coastal streams tend to be avoided by small fish species due the presence of ambush predators, such as H. malabaricus (Mazzoni \& Iglesias-Rios, 2002; Brejão et al., 2013), and aquatic birds that are very abundant in the study area.

The microhabitat parameters selected by Astyanax taeniatus cover a set of characteristics that describe areas of runs similar to those occupied by many Astyanax species from Mata Atlântica streams (Ceneviva-Bastos et al., 2010; Teresa \& Casatti, 2013; Costa, 1987; Casatti, 2002; Fogaça et al., 2003; Abilhoa et al., 2008). Nonetheless, A. taeniatus was characterized as a pool indicator in another coastal stream of the same basin (Rezende et al., 2010), corroborating the findings of Romero \& Casatti (2012) that discuss the adaptive niche plasticity of Astyanax species that allows the species to use a broader array of microhabitats and environmental features. Stream-dwelling fish species can be very plastic and tolerant to environmental changes (Abelha et al., 2001; LuzAgostinho et al., 2006; Menezes et al., 2007; Manna et al., 2012), and differences in habitat availability could be responsible for different patterns of habitat use by this group of species (Schlosser, 1982).

In summary, Astyanax taeniatus presented a nonstochastic habitat use reflecting the preference of runs characterized by deep areas with low to moderate currents and sand or bedrock substrate. Thus, the combination of all these physical parameters and their availability in the studied stream could be an important factor in the maintenance of this species in the Mato Grosso fluvial system. These results could also be used as basic parameters for the understanding of habitat use by other Astyanax species because many species of this genus respond similarly to environmental resources.

\section{Acknowledgments}

We thank Javier Lobón-Cerviá and Ricardo Iglesias-Rios for helpful comments on the manuscript. To the staff of Laboratório de Ecologia de Peixes for the assistance during the fieldwork (especially to Jean Carlos Miranda, Maíra Moraes, Raquel Costa, and Piatã Marques). This work is part of the MS.c. Dissertation of the senior author (LRM.) and was supported by grants from FAPERJ / APQ1 162 / E-26/ 110.225-2010 and CNPq personal grant to RM 300481/2010-0. This manuscript was edited for proper English language and overall style by the American Journal Experts under certificate number C880-FACB-D887-DBD7-A9C3.

\section{Literature Cited}

Abelha, M. C. F., A. A. Agostinho \& E. Goulart. 2001. Plasticidade trófica em peixes de água doce. Acta Scientiarum, 23: 425-434.
Abilhoa, V., L. F. Duboc \& D. P. A. Filho. 2008. A comunidade de peixes de um riacho de Floresta com Araucária, alto rio Iguaçu, sul do Brasil. Revista Brasileira de Zoologia, 25: 238-246.

Altmann, J. 1974. Observational study of behavior: sampling methods. Behaviour, 49: 227-265.

Angermeier, P. L. \& I. J. Schlosser. 1989. Species-area relationships for stream fishes. Ecology, 70: 1450-1462.

Aranha, J. M. R., D. F. Takeuti \& T. Yoshimura. 1998. Habitat use and food partitioning of the fishes in the Mergulhão stream (coastal stream of Atlantic Forest, Brazil). Revista de Biologia Tropical, 46: 951-959.

Arlettaz, R. 1999. Habitat selection as a major resource partitioning mechanism between the two sympatric sibling bat species Myotis myotis and Myotis blythii. Journal of Animal Ecology, 68: 460-471.

Barreto, A. P. \& J. M. R. Aranha. 2005. Assembléia de peixes de um riacho da Floresta Atlântica: composição e distribuição espacial (Guaraqueçaba, Paraná, Brasil). Acta Scientiarum Biological Sciences, 27: 153-160.

Beyer, K., G. H. Copp \& R. E. Gozlan. 2007. Microhabitat use and interspecific associations of introduced topmouth gudgeon Pseudorasbora parva and native fishes in a small stream. Journal of Fish Biology, 71: 224-238.

Brejão, G. L., P. Gerhard \& J. Zuanon. 2013. Functional trophic composition of the ichthyofauna of forest streams in eastern Brazilian Amazon. Neotropical Ichthyology, 11: 361-373.

Casatti, L. 2002. Alimentação dos peixes em um riacho do Parque Estadual Morro do Diabo, Bacia do Alto Rio Paraná, Sudeste do Brasil. Biota Neotropica, 2: 1-14.

Casatti, L. \& Castro, R. M. C. 2006. Testing the ecomorphological hypothesis in a headwater riffles fish assemblage of the rio São Francisco, southeastern Brazil. Neotropical Ichthyology, 4: 203-214.

Ceneviva-Bastos, M., L. Casatti \& D. C. R. Feres. 2010. Meso and microhabitat analysis and feeding habits of small nektonic characins (Teleostei: Characiformes) in Neotropical streams. Zoologia, 27: 191-200.

Costa, W. J. E. M. 1987. Feeding habits of a fish community in a tropical coastal stream, Rio Mato Grosso, Brazil. Studies on Neotropical Fauna and Environment, 22: 145-153.

Davey, A. J. H., S. J. Hawkins, G. F. Turner \& C. P. Doncaster. 2005. Size dependent microhabitat use and intraspecific competition in Cottus gobio. Journal of Fish Biology, 67: 428-443.

Fogaça, F. N. O., J. M. R. Aranha \& M. L. P. Esper. 2003. Ictiofauna do Rio Quebra (Antonina, PR, Brasil): Ocupação espacial e hábito alimentar. Interciência, 28: 168-173.

Gibran, F. Z. 2007. Activity, habitat use, feeding behavior, and diet of four sympatric species of Serranidae (Actinopterygii: Perciformes) in southeastern Brazil. Neotropical Ichthyology, 5: 387-398.

Gorman, O. T. 1988. The dynamics of habitat use in a guild of Ozark minnows. Ecological Monographs, 58: 1-18.

Gray, E. S. \& J. R. Stauffer-Jr. 1999. Comparative microhabitat use of ecologically similar benthic fishes. Environmental Biology of Fishes, 56: 443-453.

Inoue, M. \& M. Nunokawa. 2002. Effects of longitudinal variations in stream habitat structure on fish abundance: an analysis based on subunit-scale habitat classification. Freshwater Biology, 47: 1594-1607.

Kramer, D. L., R. W. Rangeley, L. J. Chapman \& J. G. Godin. 1997. Habitat selection: patterns of spatial distribution form behavioural decisions. Pp. 37-80. In: Godin, J. G. (Ed.) 
Behavioural Ecology of Teleost Fishes. Oxford, Oxford University Press.

Krebs, C. J. 1989. Ecological Methodology. New York, Harper Collins Publishers.

Lee, P. Y. \& J. P. Suen. 2012. Niche partitioning of fish assemblages in a mountain stream with frequent natural disturbances - an examination of microhabitat in riffle areas. Ecology of Freshwater Fish, 21: 255-265.

Liefferinge, V. C., P. Seeuws, P. Meire \& R. F. Verheyen. 2005. Microhabitat use and preferences of the endangered Cottus gobio in the River Voer, Belgium. Journal of Fish Biology, 67: 897909.

Luz-Agostinho, K. D. G., L. M. Bini, R. Fugi, A. A. Agostinho \& H. F. Julio Junior. 2006. Food spectrum and trophic structure of the ichthyofauna of Corumbá reservoir, Paraná river Basin, Brazil. Neotropical Ichthyology, 4: 61-68.

Manna, L. R., C. F. Rezende \& R. Mazzoni. 2012. Plasticity in the diet of Astyanax taeniatus in a coastal stream from Southeast Brazil. Brazilian Journal of Biology, 72: 919-928.

Mazzoni, R. \& R. Iglesias-Rios. 2002. Distribution pattern of two fish species in a coastal stream in Southeast Brazil. Brazilian Journal of Biology, 62: 171-178.

Mazzoni, R., S. A. Schubart \& R. Iglesias-Rios. 2004. Longitudinal segregation of Astyanax janeiroensis in Rio Ubatiba: a Neotropical stream of south-east Brazil. Ecology of Freshwater Fish, 13: 231-234.

Mazzoni, R., V. C. Novaes \& R. Iglesias-Rios. 2011. Microhabitat use by Phalloceros harpagos Lucinda (Cyprinodontiformes: Poeciliidae) from a coastal stream from Southeast Brazil. Neotropical Ichthyology, 9: 665-672.

Medeiros, P. R., A. T. Souza \& M. I. Ilarri. 2010. Habitat use and behavioural ecology of the juveniles of two sympatric damselfishes (Actinopterygii: Pomacentridae) in the southwestern Atlantic Ocean. Journal of Fish Biology, 77: 15991615.

Menezes, N. A., S. H. Weitzman, O. T. Oyakawa, F. C. T. Lima, R. M. C. Castro \& M. J. Weitzman. 2007. Peixes de Água Doce da Mata Atlântica: lista preliminar das espécies e comentários sobre conservação de peixes de água doce neotropicais. São Paulo, MZUSP.

Motta, P. J. 1988. Functional morphology of the feeding apparatus of ten species of Pacific butterflyfishes (Perciformes, Chaetodontidae): an ecomorphological approach. Environmental Biology of Fishes, 22: 39-67.

Motta, P. J., K. B. Clifton, P. Hernandez \& B. T. Eggold. 1995. Ecomorphological correlates in ten species of subtropical seagrass fishes: diets and microhabitat utilization. Environmental Biology of Fishes, 44: 37-60.

Munro, A. D. 1990. General introduction. Pp. 1-11. In: Munro A. D., A. P. Scott \& T. J. Lam (Eds.). Reproductive seasonality in teleosts: environmental influences. Florida, CRC Press.

Punchard, N. T., M. R. Perrow \& A. J. D. Jowitt. 2000. Fish habitat associations, community structure, density and biomass in natural and channelised lowland streams in the catchment of the river Wensum, UK. Pp. 143-157. In: Cowx, I. G. (Ed.). Management and Ecology of River Fisheries. Oxford: Blackwell Science.

Rezende, C. F., M. M. Pereira, L. R. Manna, R. P. Leitão, E. P. Caramaschi \& R. Mazzoni. 2010. Mesohabitat indicator species in a coastal stream of the Atlantic rainforest, Rio de JaneiroBrazil. Revista de Biologia Tropical, 58: 1479-1487.
Rincón, P. A. 1999. Uso do micro-hábitat em peixes de riachos: métodos e perspectivas. Pp. 23-90. In: Caramaschi, E. P., R. Mazzoni \& P. R. Peres-Neto (Orgs.). Ecologia de Peixes de Riachos. Rio de Janeiro, Computer \& Publish Editoração Ltda.

Rincón, P. A. \& J. Lobón-Cerviá. 1993. Microhabitat use by streamresident brown trout: bioenergetic consequences. Transactions of American Fisheries Society, 122: 575-587.

Roff, D. A. 1992. The Evolution of Life Histories: Theory and Analysis. London, Chapman \& Hall.

Romero, R. M. \& L. Casatti. 2012. Identification of key microhabitats for fish assemblages in tropical Brazilian savannas streams. International Revue of Hydrobiology, 97: 526-541.

Ross, S. T. 1986. Resource partitioning in fish assemblages: a review of field studies. Copeia, 1986: 352-388.

Sabino, J. 1999. Comportamento de peixes de riachos brasileiros: métodos de estudos para uma abordagem naturalística. Pp. 183208. In: Caramaschi, E. P., R. Mazzoni \& P. R. Peres-Neto (Orgs.). Ecologia de Peixes de Riachos. Rio de Janeiro, Computer \& Publish Editoração Ltda.

Sazima, I. 1980. Behavior of two Brazilian species of parodontid fishes, Apareiodon piracicabe and A. ibitiensis. Copeia, 1980: 166-169.

Sazima, I. 1986. Similarities in feeding behaviour between some marine and freshwater fishes in two tropical communities. Journal of Fish Biology, 29: 53-65.

Schlosser, I. J. 1982. Fish community structure and function along two habitat gradients in a headwater stream. Ecological Monographs, 52: 395-414.

Sedell, J. R., G. H. Reeves, F. R. Hauer, J. A. Stanford \& C. P. Hawkins. 1990. Role of refugia from disturbances: modern fragmented and disconnected river systems. Environmental Management, 14: 711-724.

Suen, J. P. \& Su, W. C. 2010. Reconstructing riverine mesohabitat unit composition using fish community data and an autecology matrix. Journal of Fish Biology, 77: 972-984.

Teresa, F. B. \& L. Casatti. 2013. Development of habitat suitability criteria for Neotropical stream fishes and an assessment of their transferability to streams with different conservation status. Neotropical Ichthyology, 11: 395-402.

Uieda, V. S. 1984. Ocorrência e distribuição dos peixes em um riacho de água doce. Revista Brasileira de Biologia, 44: 203-213.

Weatherley, A. H. 1963. Notions of niche and competition among animals, with special reference to freshwater fish. Nature, 197: 14-17.

Wootton, R. J. 1998. Ecology of Teleost Fishes. New York, Chapman and Hall.

Yamasaki, Y., S. Haramoto \& T. Fukasawa. 2006. Habitat uses of freshwater fishes on the scale of reach system provided in small streams. Environmental Biology of Fishes, 75: 333-341.

Zar, J. 1999. Biostatistical analysis. New Jersey: Prentice Hall.

Submitted November 24, 2012 Accepted January 1, 2014 by Fabricio Teresa Published March 31, 2014 